\title{
US role alleged in cover-up of researchers guilty of war crimes
}

\section{Cologne}

NEW evidence that the United States helped to cover up crimes committed during the Second World War by Japanese and German physicians was presented last week at a conference here entitled "Medical Science without Compassion, Past and Present".

Historians, physicians and genetecists spoke at the conference, which was organized by geneticist Benno Müller-Hill. Most talks concerned Nazi medical crimes - the participation of doctors and especially psychiatrists; the continuity of the German sterilization and euthanasia programmes of the 1930 s with the murder of Jews and gypsies; and the lack of contemporary or even subsequent condemnation by the medical and scientific community. Müller-Hill said that he organized the conference because "the attack on Nazi science in West Germany had been left to what I'd call anti-science groups" and "I'd like to take this topic away [from them]." This conference was supported by the Deutsche Forschungsgemeinschaft, a research funding organization.

The alleged use of prisoners in biological warfare experiments in Manchuria by Japanese physician Shiro Ishii was described by Sheldon Harris of California State University at Northridge. Harris claimed that Ishii moved to the United States in 1948 and lectured at the US biological weapons research station at Fort Detrick, Maryland. No Japanese physician was ever prosecuted for war crimes.

"At least 3,000 prisoners" died in Ishii's experiments at the Ping Fan camp in Manchuria between 1937 and 1945, said Harris. Ping Fan was established under the pretence of being a lumber mill, and the prisoners were allegedly known to their captors as "logs."

Ishii was said to have studied the immunological response against pathogens ranging from typhoid and dysentery to anthrax. He also developed vaccines against diseases caused by these and other agents. The Ping Fan facility produced at least 20 million doses of vaccine annually.

Harris cited official denials that human subjects were used in Japanese biological warfare experiments. But Harris said that a US intelligence report from 1947 noted that "experiments on humans were known to and described by three Japanese and confirmed tacitly by Ishii".

A 1947 official report submitted by a US Navy commander to the State War Navy Coordinating Subcommittee for the Far East stated that "at least 12 bacteriological warfare weapons field trials were conducted against Chinese military and civilian populations". Harris claimed that US prisoners were also used for the experiments, although the report denied this

Humans were used for both laboratory testing of the immune response, according to the report, as well as for field trials. According to Harris, Ishii's capture by US occupation forces in Japan in 1946 was considered "a great coup for the advancement of US biological warfare research". Negotiations with Ishii lasted throughout 1947, said Harris, with Ishii offering as bargaining chips "tantalizing disclosures about human experimentation".

US negotiators informed higher authorities all the way up to the Joint Chiefs of Staff, said Harris, who then authorized each succeeding round of negotiations. US leaders were allegedly concerned as early as 1947 that the US government might by "seriously embarrassed", according to the minutes of the State War Navy Coordinating Committee, if it came out that these negotiations were carried out with Japanese physicians at the same time as German doctors were being prosecuted at Nuremberg for experimenting on humans. But interest in Ishii's experiments, said Harris, overrode all moral and political concerns

West German physician Christian Pross revealed new evidence on the dual role played by one US investigator, the Vienna-born Boston neurologist Leo Alexander, in preparing war crimes cases while looking for "valuable results" that could be used by US medical science.

Pross contends that Alexander's reports reflect a mixture of ethical condemnation of the Nazi scientists and admiration of their "objective and accurate observation and interpretation". Alexander, he said, had worked in Germany until the Nazi takeover forced him to flee in 1933.

Pross sees evidence for US government manipulation in the change of heart of Andrew Ivy, a physiology professor at the University of Illinois, Chicago, in his Nuremberg testimony at the so-called "doctors' trial" of 1946-47. Ivy had filed a report condemning two of the German physicians on trial as accessories to the notorious Sigmund Rascher in his hypothermia and high-altitude experiments on human subjects at Dachau. The physicians, Siegfried Ruff and Hans-Wolfgang Romberg, claimed that they had not done any experiments in which subjects died.

On the witness stand, Ivy made very different statements. He defended the legitimacy of using human subjects for wartime research. Ruff and Romberg were acquitted and Ruff went on to become director of the Aeromedical Institute of the Bundeswehr, West Germany's army.
SDI chief quits as funds are cut

\section{Boston}

Lt-General James Abrahamson, director of the Strategic Defense Initiative (SDI), has resigned his post with effect from January 1989, the Pentagon unexpectedly announced last week. The announcement of Abrahamson's resignation came the day before Congress approved a military spending bill that will halt the growth of funds for the programme for the first time in its five-year history.

Abrahamson's departure, which will coincide with that of the Reagan administration, is expected by many analysts to mark the end of an era for the controversial anti-missile defence system.

The timing of Abrahamson's decision to leave seems clearly tied to prospects that a new administration will probably scale down the project's budget, and the attention given to it. In his letter of resignation, Abrahamson stated that "a new administration will undoubtedly have different ideas or approaches" to SDI and that "new leadership" would best represent the "new policy and direction".

While the Congress has agreed to allot $\$ 4.1$ thousand million to the SDI programme for fiscal year 1989 (which began on 1 October), the stagnation of the budget comes after many years of sharp increases. It seems generally agreed that in either a Bush or a Dukakis administration, this figure will represent a "highwater mark" for the programme. Armscontrol expert Ashton Carter, acting director of the Center for Science and International Affairs at Harvard University, predicts that, without President Reagan's strong advocacy, it is likely that SDI will return to the status of "just another R\&D project" at the Pentagon.

Vice-President Bush, in his campaign for the presidency, has affirmed his support for the SDI programme, but Carter says that pressures to restrain the federal budget may be strong enough to force reductions under any administration. Governor Dukakis has stated that, if elected, his administration would cut the project's funds by as much as $\$ 3,000$ million.

During his tenure, Abrahamson has opposed vigorously any proposals to limit the programme's scope or delay its ambitious plan to begin testing by the 1990 s.

Abrahamson, 55, has been head of the research programme since 1984 , when the position was elevated to a special new post in the Pentagon. On his departure, he will retire from active military duty. The Pentagon has nominated as his successor Lt-General George Monahan Jr, now the Principal Deputy Assistant of Acquisition for the Air Force. His nomination must be confirmed by Congress. Seth Shulman 